\title{
Logos dan Sophia dalam Perjanjian Baru
}

Adolfina Elisabeth Koamesakh

Sekolah Tinggi Teologi Paulus Medan, Sumatera Utara

finaadolfina@gmail.com

\begin{abstract}
Hearing about the word "logos" often cause people been set of leading their thoughts to the confusing Greek philosophy. Indeed for Greek philosophers, the word refers to the group of angels they know by the name demiourgos. This demeourgos angel according to Greek philosophy became human. If this thought is followed, then what turns into a person is not God but angels. For this reason, the notion of logos according to Christianity differs from the beliefs of philosophers. Christian logos are: God's incarnated Word.
\end{abstract}

Keywords: incarnate; logos; New Testament; sophia; the word of God

\begin{abstract}
Abstrak: Mendengar kata "logos" seringkali orang terjebak yang mengarahkan pikirannya ke filsafat Yunani yang membingungkan itu. Memang bagi filsuf Yunani, kata itu mengarah kepada kelompok malaikat yang mereka kenal dengan nama demiourgos. Malaikat demeourgos inilah menurut filosofi Yunani yang menjadi manusia. Jikalau pemikiran ini diikuti, maka yang menjelma menjadi manusia itu bukkan Allah tetapi malaikat. Karena itulah, pengertian logos menurut Kekristenan berbeda dengan keyakinan para filsuf. Logos orang Kristen adalah: Firman Allah yang menjelma.
\end{abstract}

Kata Kunci: firman Allah; logos; menjelma; Perjanjian Baru; sophia

\section{PENDAHULUAN}

Abad kedua adalah fase dimana gereja mulai berbicara tentang keberadaan pribadi-pribadi dalam Allah Tritunggal, khususnya tentang hubungan pribadi Kristus dengan Allah. Usaha untuk merumuskan Kristologi, sering membuat seseorang atau kelompok-kelompok teolog tertentu gagal dalam menemukan rumusan yang sesuai dengan kebenaran Injil, dan dikutuk sebagai bidat atau penyebar ajaran sesat. Meski pada masa para rasul sudah bermunculan berbagai pandangan Kristologi yang dibayangi oleh aliran filsafat gnostik Kristen tetapi tekanan yang semakin kuat terjadi pada masa sesudah para rasul, kaum apologet dan masa bapa-bapa Gereja atau yang dikenal dengan periode gereja di masa konsili-konsili Agung.

Salah satu ajaran tentang Tritunggal Kudus yang muncul pertama kali mengatakan bahwa Allah memiliki satu pribadi saja, dan Allah itu juga telah menjelma serta mengalami konskuensi kefanaan manusia, antara lain: menderita, dan mati. Golongan ini dikenal dengan nama patropaschitas (Bapa/Allah ikut menderita) atau monarchian = hanya satu oknum (180). Monarchian disebut juga docitisme yang menyangkali adanya kemanusiaan yang ril dari Kristus. Nama Savelius (220) sebagai seorang tokoh yang menghasilkan 
dogma peran atau modalisme untuk menghubungkan antara Bapa, Putra dan Roh. Doktrin ini menyebutkan bahwa Allah adalah "Bapa dalam Perjanjian Lama, Putra dalam Perjanjian Baru, dan Roh Kudus dalam Gereja.”

\section{METODE PENELITIAN}

Jenis penelitian ini adalah penelitian kualitatif literatur, dengan membaca beberapa buku yang berkaitan dengan logos dan sophia lalu disoroti dengan pengertian Kristen. Ada beberapa hal yang dideksripsikan dalam pembahasan ini. Pertama, berkaitan dengan pribadi Kristus, muncul pemahaman pengadopsian keputraan Yesus yang diberikan kepada Yesus saat pembaptisan-Nya. Yesus hanya sebagai manusia biasa sebelum dibaptis dan ketika Roh Allah turun ke atasNya barulah ia diadopsi/diangkat menjadi anak Allah.

Paham ini masih mempertahankan bahwa Allah Bapa yang menjelma dalam diri Yesus Kristus, sementara Yesus sendiri adalah manusia biasa. Dengan kata lain Allah Bapa hanya menumpang pada tubuh seorang bernama Yesus. Tetapi persoalan yang sulit diselesaikan oleh kaum monarchisme adalah bagaimana Allah yang Roh dapat menderita dan mengalami kematian? Jika Yesus adalah hanya manusia biasa dan baru diadopsi sebagai anak Allah pada waktu pembaptisanNya, maka bagaimana menjelaskan kapan Allah masuk ke dalam diri Yesus yang manusia itu dan bagaimana caranya? Seorang pengikut konsep adopsi adalah uskup Antiokhia (260), Paulus Samosateus. Samosateus tidak saja menggunakan kata "putra" untuk Yesus, tetapi juga kata logos untuk menjelaskan hubungan antara Allah dan Yesus. Ia berpendapat bahwa Logos Allah yang tidak berpribadi itu adalah kekuatan ilahi. Dalam hal ini Logos sama dengan Roh Kudus, yaitu Roh yang ada dan bekerja melalui para nabi, seperti Musa, tetapi logos atau roh ini memiliki kekuatan yang lebih besar dari roh yang ada pada para nabi tersebut. Pembicaraan tentang logos diteruskan oleh Arius yang dikutuk Gereja pada sinode pertama di Nicea 325 karena menggolongkan logos Allah dalam ciptaan umumnya. Logos menurut Arius diciptakan dari yang tidak ada, sama seperti Allah menciptakan ciptaan lainnya. Kemudian ia mengambil bagian dalam keallahan Allah. Arius juga menyebutkan Sophia sama halnya dengan logos diciptakan karena keinginan Allah untuk menciptakan manusia dan semesta, supaya melalui keduanya segala sesuatu masuk ke dalam eksistensi mereka. Dapat dikatakan bahwa pembicaraan tentang Logos dan Sophia dihubungkan dengan penciptaan yang diceritakan oleh Musa dalam kitab Kejadian mewakili seluruh Perjanjian Lama. Dan Yohanes rasul Kristus memahami hal yang sama melalui Injil dan suratnya ketika ia menghubungkan Logos dengan penciptaan dunia ini. Logos adalah 'mediator' dari semua yang diciptakan untuk menghubungkan Allah dengan manusia.

Logos Allah dalam prolog Injil Yohanes (1:1-18) telah menjadi kajian dogmatis terhadap Kristologi dari masa ke masa, dan sejarah membuktikan bahwa banyak teolog pada akhir abad kedua sampai abad keempat gagal dalam menerjemahkan Kristologi Yohanes, secara khusus pada pemahaman Logos yang dihubungkan dengan hakekat keilahian Kristus. Prolog ini menguatkan top down Kristologi Yohanes yaitu suatu pendekatan dogmatis yang dimulai dari hakekat keilahian Yesus kemudian masuk ke 
dalam eksistensi kemanusiaan-Nya yang nyata. Pendekatan semacam ini umumnya digunakan oleh kekeristenan Timur sejak awal abad-abad pertama, dan mendapat penekanan khusus pada hasil sidang Sinode I di Nicea tahun 325.

Meskipun sinode ini tidak menggunakan istilah logos tetapi menggantikannya dengan kata terang untuk membicarakan kesejatian ke-Allahan Putra Allah. Yohanes sendiri hanya menggunakan istilah logos pada bagian prolog saja, karena sepanjang injil dan suratnya yang lain, ia menggunakan beberapa istilah lain untuk merujuk kepada eksistensi pra penjelmaan Kristus menjadi manusia, yang antara lain adalah kata terang (Yoh. 8:12) dan firman hidup (1 Yoh. 3) bahwa prolog dalam Injil Yohanes memberikan tiga unsur mediatorship yaitu: pengentaraan dalam ciptaan (creation, ayat 10), dalam pewahyuan(revelation, 4,5,9) dimana Ia adalah Terang, dan Kebenaran. Dan yang ketiga adalah mediator dalam keselamatan (salvation) 12, 13 bagi mereka yang percaya kepadaNya diberi hak menjadi anak-anak Allah.

Butir kedua Pengakuan Iman Nicea: “aku percaya kepada satu Tuhan Yesus Kristus, Anak Tunggal Allah. Yang diperanakkan dan bukan bukan diciptakan, satu hakikat dengan sang Bapa. Terang yang keluar dari Terang, Allah sejati yang keluar dari Allah sejati..." (Yoh. 1:1). Tetapi Yohanes tidak menggunakan kata hikmat dalam Injilnya, seperti yang ditemukan dalam surat-surat Paulus. Diskusi ini dikemas dalam pertanyaan-pertanyaan berikut: Pertama, apakah Logos adalah Anak Allah? atau Logos berbeda pribadi dengan Anak Allah? Kedua, apakah Logos sama kekalnya dengan Allah? Ketiga, apakah Sophia adalah satu pribadi dengan Logos adalah pribadi yang berbeda dari logos? Keempat, apakah Logos dan Sophia dipahami hanya sebagai kekuatan Allah karena keduanya adalah mediator Allah dalam mencipta?

\section{PEMBAHASAN}

\section{Konsep Logos dan Hikmat}

Kata logos memiliki makna kata yang beragam. Collins Greek-English Dictionary memberikan beberapa arti yang memiliki arti yang sejajar dengan bahasa Yunani yaitu: Speech, yaitu: penggunaan bahasa untuk komunikasi; khotbah; reason, yaitu pikiran, akal budi, alasan; ratio, yaitu konsep dalam matematika. Kata logos dalam konsep filsafat (Plato) yaitu bagian dari nous yang dengannya Allah yang tenang (silent) itu beraktivitas. Word, perkataan, janji; teologia: firman.

Hakikat logos menurut Eusebius T.E Pollard memberikan lima kemungkinan arti dari kata Logos:

1) Reason yang adalah dasar dari jiwa yang rasional yang membuat manusia mampu berpikir;

2) sebuah kata yang ketika diungkapkan memberikan suatu arti;

3) suatu tulisan (i.e artikel. tesis) yang ditulis oleh seorang penulis;

4) suatu benih (seminal) logos yang dikenal juga dengan ungkapan,yaitu logos yang masih berpotensi (dynami) untuk masuk ke dalam keberadaannya (energia);

5) kemampuan (kapasitas) untuk mengakses pengetahuan, seperti seni atau ilmu lainnya. 
Menurut Eusebius kelima pengertian di atas tidak memiliki dasar dalam konsep logos Injil Yohanes. Tiga klausa dalam 1:1, yakni: pada mulanya adalah Firman; Firman itu bersamasama dengan Allah; Firman itu adalah Allah, merupakan pernyataan yang absolut tanpa ada yang perlu ditambahkan atau arti lain yang tidak tercakup di dalam klausa-klausa tersebut. Ayat ini memiliki corak konstruksi sylogismos Aristoteles dalam bentuknya (bukan isi). Perhatikan:

Premis 1: Pada mulanya adalah firman.

Premis 2: Firman itu bersama Allah.

Thesis (maka) firman itu adalah Allah.

Menurut Eusebius ${ }^{1}$ "firman itu ada di dalam Allah", maka sejak Allah itu ada, FirmanNya juga ada bersama-Nya. Ungkapan pada mulanya tidak menunjukkan adanya awal dari Allah. Dengan demikian maka Logos memiliki pra kekekalan yang sama dengan BapaNya, kecuali ada petunjuk kapan Allah mulai ada di masa yang lalu sebelum dunia diciptakan.

Kata sophia dalam bahasa Yunani memiliki kata yang sejajar dalam bahasa Inggris wisdom dan hikmat dalam bahasa Indonesia. Lalu apa arti dari hikmat? Hikmat memberi arti pengetahuan (knowledge). Jika seseorang dikatakan memiliki hikmat artinya ia memiliki pengetahuan. Kata ini erat hubungannya dengan pengetahuan (gnosi) dan pada masa era Helenisme-Romawi kaum filosuf (philo + Sophia = mengidolakan atau mencintai hikmat/pengetahuan) adalah orang-orang yang dianggap sebagai sumber berbagai pengetahuan. Dan seorang filosuf selalu mencari dan menemukan jawaban bagi persoalanpersoaan yang berhubungan dengan manusia, semesta dan Allah yang tak kelihatan. Dasar pemikiran semacam inilah, maka para filsuf adalah guru dari beberapa murid yang hidup bersama untuk belajar memperoleh pengetahuan.

Artinya, hikmat tidak saja diasosiasi dengan kata bijaksana tetapi juga dengan pengetahuan. Pengetahuan di sini tidak dimaksudkan sebagai ilmu yang dikuasai oleh seseorang, tetapi hakekatnya adalah pengetahuan akan kebenaran yang menghubungkan manusia dengan alam semesta dan Allah sebagai pencipta. Dimensi dari pengetahuan itu bersifat abadi karena berkaitan dengan sebuah kebenaran yang absolut.

\section{Logos dan Hikmat dalam Kitab Perjanjian Baru}

Bagian prolog Injil Yohanes memberikan informasi penting sekaligus menguatkan Kristologi Yohanes yang banyak didiskusikan oleh para pemikir Kristologi. Meski demikian Yohanes tidak menggunakan kata hikmat untuk mengidentikkannya dengan logos. Grillmeier memberikan dua kemungkinan mengapa Yohanes tidak memakai kata

${ }^{1}$ T.E. Pollard. Johannine Christology and the Early Church, Cambridge (The University Press:1970), 281. Dari kelima definisi itu tidak ada satupun yang merepresentasikan pemahaman Logos dalam Injil Yohanes. Logos spermatikos misalnya, ditentang oleh Vasilus Agung (dalam Athanasius erga 3, hal, 203) karena menempatkan Logos atau Yesus sama dengan ciptaan lain seperti: tumbuhan, biji, atau benih lainnya yang memiliki potensi untuk bertumbuh. Sementara Logos dalam Injil Yohanes justru adalah kekuatan itu sendiri dan melaluiNya segala yang ada dan tercipta ini mendapat eksistensi mereka. Dengan kata lain logos= Yesus adalah Pencipta itu sendiri. 
sophia. Pertama bahwa kata sophia 'baik dalam bahasa Yunani maupun Ibrani bergender feminine" sementara logos atau d'bhar dalam bentuk maskulin. Tetapi alasan kedua yang lebih kontektual pada masa itu, bahwa Yohanes menghindari memakai konsep yang sedang diidolakan oleh kaum gnostik Kristen pada masa itu, yang menekankan pengetahuan (gnosis) yaitu pencapaian mengenal Allah. Yang menarik dari prolog ini jika dilihat dari sudut sastra membentuk suatu syair sebuah hymne Kristologi yang menarik untuk direnungkan. Pater Ionnnes Skiaderisis dalam tulisannya mencatat bahwa hymne Kristologi ini terdiri atas 30 baris dalam empat bait.

I. A.

1. a. pada mulanya adalah firman

b. dan firman itu (ada didepan) bersama Allah

c. dan firman itu adalah Allah

2. Ia pada mulanya (berada) bersama-sama dengan Allah

I. B.

3. a. Segala sesuatu dijadikan melalui Dia

b. Dan tanpa Dia tidak ada suatupun yang telah terjadi

c. Dari segala yang yang telah terjadi

II. A.

4. a. Di dalam Dia ada hidup

b. dan hidup itu adalah terang manusia

5. a. dan terang itu bercahaya di dalam kegelapan

b. dan kegelapan itu tidak menguasai (mengenal)nya

II. B.

6. a. Ia adalah terang yang sejati

b. yang menerangi setiap orang

c. (terang itu) sedang datang ke dalam dunia

III. A.

7. a. ia telah ada di dalam dunia

b. dan dunia tidak mengenalnya

8. a. Ia telah datang kepada milik kepunyaan-Nya

b. tetapi orang-orang kepunyaan-Nya itu tidak menerima Dia

III. B.

9. a. tetapi semua orang yang menerimanya

b. Ia memberikan mereka hak

c. (hak) menjadi anak-anak Allah.

IV. A.

10. a. Firman itu telah menjadi manusia

b. dan tinggal (berkemah) diantara kita

c. dan kita telah melihat kemuliaanNya

d. kemuliaan sebagai Anak Tunggal Bapa

e. Penuh kasih karunia dan kebenaran 
IV. B.

11. a. Karena dari kepenuhanNya

b. kita semua telah menerima

c. anugerah demi anugerah

Ayat-ayat di atas disusun seperti susunan sebuah sajak yang cukup panjang dengan alur pamahaman yang dimulai dari tingkat abstrak kepada yang lebih konkrit. Yohanes mulai dari firman yang ada bersama Allah, kemudian beralih kepada hidup dan terang, dan pada puncaknya ia menyebutkan bahwa firman itu telah menjadi manusia. Sebagai manusia ia bisa dilihat, diraba dan disaksikan.

Frasa "pada mulanya adalah firman" menekankan dua hal penting yaitu:

1) Pra kekekalan dari sang Firman. Yaitu Firman Allah sama seperti Allah tanpa memiliki awal.

2) Kesatuan firman dengan Allah adalah kesatuan dalam hakekat. Firman merujuk kepada hikmat dan akal budi (reason) sama seperti diartikan juga sebagai kata-kata. Kata hikmat dan akal budi dalam bahasa Yunani logikos dihubungkan kepada arti creation (dimiourgos) atau creator. ${ }^{2}$

$\operatorname{Logos}^{3}$ inilah yang kemudian menjadi daging atau manusia. Yohanes menggunakan kata sarx. Meskipun kata sarx memiliki beberapa arti yang memberikan referensi yang berbedabeda, tetapi Yohanes dalam ayat-ayat berikutnya merujuk kepada satu pengertian yaitu manusia. Penggunaan kata ini telah membagi para teolog pada lima abad pertama ke dalam dua mazhab (aliran) yang dikenal dengan mazhab Alexandria dan mazhab Antiokhia.

Para teolog Alexandria cenderung kepada pemahaman bahwa kata logos menjadi sarx dalam pengertian umum yaitu daging biasa yang tidak memiliki logika/jiwa. Sementara model yang kedua diwakili oleh para teolog Antiokhia yang memahami bahwa Logos Allah bersatu dalam tubuh dan jiwa sebagaimana manusia pada umumnya. Dan hakekat/substansi Keallahan Logos itu berada pada jiwa yang memiliki logika (reason), karna disanalah tempatnya. ${ }^{4}$

Perdebatan mengenai logos menjadi daging dan logos menjadi manusia memberikan konsekuensi yang berbeda. Logos menjadi daging bagi Apolinarios dan Arius serta aliranaliran lain yang sama dengannya mengatakan bahwa tidaklah mungkin dua hakekat yang sempurna berada dalam satu pribadi, oleh karena itu, Kristus bukan saja memiliki dua hakekat tetapi juga dua pribadi. Persoalan yang menarik adalah pada dua pribadi dalam Yesus. Menurut mereka pribadi yang satu adalah logos menjadi daging dalam pengertian

${ }^{2}$ dalam menentang ajaran docetisme yang menyangkali adanya fakta kemanusiaan Yesus, rasul Yohanes dalam suratnya I Yoh.1:1 ia mendasari Kristologinya pada fakta historis pengalamannya bersama Gurunya yang adalah Firman itu sendiri. "Apa yang telah ada sejak semula yang telah kami dengar, yang telah kami lihat dengan mata kami, yang telah kami saksaikan dan yang telah kami raba dengan tangan kami tentang Firman hidup - itulah yang kami tuliskan kepada kamu."

${ }^{3}$ Sarx bisa dimengerti sebagai 1) daging yang dimakan, 2) kedagingan manusia = karkater duniawi/badaniah, 3) kemanusian manusia yang terdiri dari darah-daging yang membedakannya dari makhluk lain 4) manusia secara utuh

${ }^{4}$ Theodoros, Zisis, I Soteria tou anthropu, Paterika 2. Theanthropos. Thessalonika: 1971. 180 Para teolog Alexandria merumuskan berbagai Kristologi yang menjelma ke dalam berbagai aliran bidat seperti appoliniarisme, Arianisme. 
daging tanpa roh/jiwa atau tanpa nous-mind, dan logos yang menyatu dengan jiwa manusia yang memiliki nous.

Pertama, Logos daging = tanpa nous/logika/roh = kemanusiaan Yesus. Kedua, Logos daging $=$ jiwa yang memiliki logika keilahian. Agios Athanasius menyadur pemahaman Logos kaum Arianisme dan aliran-aliran yang serupa dengan mereka sebagai berikut:

Allah tidak selalu Bapa. Karena pada masa sebelumnya pernah bukan sebagai Bapa, karena pada masa itu hanya ada Allah saja dan bukan Bapa. Tetapi kemudian Ia menjadi Bapa. Putra juga demikian sebelumnya tidak ada.sama seperti segala sesuatu diciptakan dari ketiadaan, demikian juga Logos telah diciptakan dari nihil, sehingga ada masa di mana dulu ia tidak ada...jadi pernah ada di masa lampau hanya Allah tanpa Logos dan Sophia. Kemudian ketika Allah mau menciptakan kita maka Dia menciptakan oknum yang ia sebut Logos, Sophia, atau Putra. Sehingga melalui Dia kita diciptakan...menurutnya terdapat dua macam Sophia: yang satu ada bersama Allah, dan yang satu menjadi Putra (putra berasal dari Sophia) dan hanya anugerah ia disebut Logos dan Putra (bukan secara hakekat).

Jadi menurut Arius bahwa terdapat pada Allah dua jenis Logos: Logos yang bersama Allah, dan Logos atau Putra berdasarkan anugerah saja, dan bukan hakikat.

Konsekuensi dari pemahaman ini adalah bahwa Putra Allah atau Logos atau Hikmat tidak sama hakikatnya dengan Allah. Bahkan logos kedua bukan datang langsung dari dalam diri Allah tetapi dari hikmat yang Allah sendiri ciptakan. Kesimpulan yang dapat digambarkan disini adalah sebagai berikut: Pertama, Allah menciptakan Logos atau Hikmat atau Putra. Kedua, ada dua Sophia yang dicptakan Allah, yaitu: Sophia yang khusus berada bersama Allah; dan Sophia yang menjadi sumber dari keberadaan Putra dan dianugerahkan nama sebagai: Putra atau Logos.

Menjawab doktrin Arianisme, Athanasius mengatakan bahwa: "Firman adalah Allah yang berasal dari Allah karena Dia adalah Allah yang berasal dari Allah dan Dia adalah Logos, Sophia, Putra, dan kekuatan Allah, serta Kristus, maka Dia adalah satu-satunya Allah yang diberitakan di dalam kitab-kitab Suci." Oleh karena itu maka sumber kealahan itu hanya satu, dan Putera Allah hanya satu, yang memiliki zat atau hakikat yang sama dengan Bapa. Sebagaimana Bapa tanpa awal maka keilahian Putera (Logos) juga tanpa awal. Sementara teolog Antiokhia membicarakan tentang Kristus sejarah dengan penekanan pada baik kesempurnaan kemanusiaan sang Logos dan kesempurnaan keilahian dari Logos dalam satu pribadi yaitu Yesus Kristus.

Frasa Firman itu bersama Allah dalam bentuk past tense, merujuk kepada keberadaan Logos itu sebelum menjadi manusia, Ia berada bersama Allah (Bapa) sekaligus memberikan indikasi bahwa, Logos adalah pribadi yang berbeda dengan Bapa, maupun Roh. Di dalam Injil Yohanes pasal pertama ini, Yohanes menggunakan kata Logos dan anak Tunggal yang harus dimengerti bahwa baik logos maupun Putra bukanlah dua pribadi tetapi satu pribadi. Logos adalah putra dan putra adalah Logos itu sendiri. Agios Athanasius dalam perdebatannya dengan Arius, ia mengatakan bahwa Logos dan Putra “...bukanlah dua tetapi satu. Yang ada pada pangkuan Bapa itu hanya satu yaitu Putra yang adalah anak tunggal Bapa. Jika Logos itu adalah oknum lain dan Putra adalah oknum lain, 
maka Putra pasti lebih tinggi dari Logos karena hanya Putra yang mengenal Bapa, tidak ada yang lain." Oleh karena itu Logos adalah pribadi yang sama dengan Putra dan Sophia.

\section{Sophia (Hikmat)}

Pengertian kata Sophia yang diberikan di atas menunjukkan adanya hubungan yang erat erat dengan konsep kata nous (mind), gnomi (knowledge), dan psichi (jiwa) yang memilki logika (reason). Para teolog Yunani tidak membedakan pengertian sophia dan logos. Kedua-duanya memiliki arti atau konsep yang sama, karena word adalah sama dengan logos. Oleh karena itu Athanasius menggunakan kata: "Logos = Wisdom = Yesus Kristus dengan berdasar kepada tiga text yaitu Mazmur 104: 24, “...sekaliannya Kau jadikan dengan kebijaksanaan, bumi penuh dengan ciptaanMu. Lalu, dalam Yohanes 1:3 "segala sesuatu telah dijadikan melalui "Logos" dan tanpa dia tidak ada suatupun telah jadi..." Kemudian, I Korintus 8:6, "Hanya ada satu Allah yaitu Bapa, yang dariNya berasal segala sesuatu...dan satu Tuhan, Yesus Kristus, yang olehNya segala sesuatu telah dijadikan..."

\section{Hikmat Menurut Paulus}

Rasul Paulus dalam suratnya yang pertama kepada orang-orang Korintus, ia menuliskan: “...Kristus adalah kekuatan Allah dan hikmat Allah..." Pada konteks ini Paulus mempertentangkan antara hikmat Allah (Yesus Kristus) dengan hikmat manusia. ${ }^{5}$ Dalam hubungannya dengan pemberitaan Injil Kristus Paulus menegaskan bahwa ia tidak menggunakan 'hikmat perkataan' karena perangkat hikmat filosofis tidak sanggup untuk menguraikan arti keselamatan melalui salib (karena salib adalah suatu kebodohan) kemudian Paulus memberikan suatu konklusi ditengah-tengah pembahasannya bahwa "Yesus adalah hikmat Allah". Jika hikmat diartikan sebagai gnomi (knowledge) maka Kristus adalah pengetahuan itu sendiri.

Pertanyaannya adalah, pengetahuan apa? Paulus menjawab "rahasia Allah." Lalu siapa yang mengetahui rahasia Allah? Yohanes menjawab: "tidak seorangpun yang pernah melihat Allah; tetapi Anak Tunggal Allah yang ada di pangkuan Bapa, Dialah yang menyatakan-Nya." Selanjutnya apa yang dinyatakan (sebelumnya rahasia) oelh Anak Tunggal Allah?

Paulus dalam 1Korintus 2:6-8 menghubungkan hikmat Allah dengan berita Injil yang disampaikan oleh para rasul, yaitu Injil = pribadi Yesus Kristus yang mati dan menyelamatkan manusia. Pernyataan "hikmat Allah yang tersembunyi dan rahasia..." keselamatan dalam Yesus sudah ditentukan Allah bagi orang percaya sejak sebelum dunia diciptakan. Inilah keselamatan yang dilakukan oleh Yesus melalui kematianNya di salib. Bagi hikmat (pengetahuan) dunia salib adalah kebodohan tetapi bagi Paulus salib adalah hikmat Allah. Hal yang sama dibicarakan oleh Athanasius Agung: "Sophia adalah awal dan penuntun kepada pengetahuan akan Allah". ${ }^{6}$ Oleh karena itu Solomo dalam sebuah

\footnotetext{
5 T.E Pollard, Johannine Christology and the Early Church, (Cambrige: Univ. Press, 1970), p. 199

${ }^{6}$ Kolose 1: 15 "Ia adalah gambar Allah yang tidak kelihatan, yang sulung, lebih utama dari segala yang diciptakan." Ibrani 1: 3 "Ia adalah cahaya kemuliaan Allah dan gambar wujud Allah dan menopang segala yang ada dengan firman-Nya yang penuh kekuasaan."
} 
ayatnya yang terkenal ia mengatakan "permulaan pengetahuan adalah takut akan Tuhan". Demikian juga Yohanes mengutip perkataan Tuhan Yesus kepada murid-murid-Nya "Akulah jalan dan kebenaran dan hidup. Tak seorangpun sampai kepada Bapa, kalau tidak melalui Aku." memiliki relevansi yang erat dengan pengetahuan akan Allah.

Pernyataan Yohanes di atas mengandung arti, bahwa hanya melalui Yesus manusia mencapai pengetahuan akan kebenaran; hanya melalui Yesus manusia berada pada jalan menuju akhir yang kekal; dan, hanya Yesus yang mengetahui Bapa yang adalah tujuan dari kehidupan ini. Dan ketika manusia memiliki Yesus yang adalah hikmat Allah itu, manusia memperoleh pengetahuan akan Bapa Surgawi.

\section{Hikmat Menurut Athanasius Agung}

Athanasius adalah tokoh utama yang paling banyak menulis menentang ajaran Arius yang merendahkan keilahian Yesus Kristus dan pemahaman monarkhisme keilahian dari Tritunggal Allah dalam konsep Perjanjian Baru. Allah adalah Allah yang berhikmat (Sophos) atau yang memiliki hikmat. Dan melalui hikmat-Nya Ia menciptakan, berkarya, dan menebus ciptaan-Nya. Athanasius menghubungkan hikmat dengan kehendak kekal Allah yang ingin membuat dirinya diketahui/dikenal oleh ciptaan-Nya. Oleh karena itu Ia menciptakan manusia menurut 'gambar (icon) dan rupa' Nya sendiri.

Ikon Allah dalam diri manusia adalah suatu perangkat dalam diri manusia untuk mengenal Allah, dan menurut Athanasius ini adalah 'bayangan sophia' itu sendiri karena Sophia yang sejati adalah Firman-Nya yang menambahkan ke dalam diri-Nya keberadaan manusia, hakekat manusia yaitu menjadi manusia secara utuh. Dengan keberadaan-Nya sebagai manusia Ia menahankan penderitaan salib hingga mati bagi keselamatan semua orang yang percaya kepada-Nya melalui iman. BagiAgios Athanasius Sophia berbicara tentang dua hal. Pertama, Sophia diartikan sebagai gambar Allah dalam diri manusia yang melaluinya manusia mengenal Allah. Kedua, Sophia yang sejati adalah Logos yaitu Firman Allah yang menjadi manusia dan dikenal dengan nama Yesus Kristus. Dia adalah gambar Allah yang sejati.

Dengan kata lain bahwa kehendak Allah untuk mengungkapkan diri-Nya kepada ciptaan, Ia lakukan melalui gambar-Nya dalam diri manusia tetapi pengungkapan (penyataan) diri Allah yang besar adalah melalui Sophia, yang tidak lain adalah sang Firman atau Logos yang menjadi manusia (Yoh.1:14). Meskipun demikian Alkitab tidak mengatakan sophia menjadi manusia tetapi Logos menjadi sarx (daging). Kolose 1: 15 "Ia adalah gambar Allah yang tidak kelihatan, yang sulung, lebih utama dari segala yang diciptakan." Bandingkan dengan Ibrani 1:3, "Ia adalah cahaya kemuliaan Allah dan gambar wujud Allah dan menopang segala yang ada dengan firman-Nya yang penuh kekuasaan."

\section{KESIMPULAN}

Perjanjian Baru membicarakan satu pribadi yaitu Yesus Kristus yang memiliki dua hakIkat, yaitu manusia dan Allah (Theanthropos). Keallahan Yesus terletak pada pribadinya sebagai Putra, Logos, dan Hikmat Allah. Logos atau Putra adalah pribadi kedua 
dari Tritunggal yang merupakan hikmat, gambar, cahaya, dan kekuatan Allah dalam menciptakan, memelihara dan menebus ciptaanNya. Hikmat adalah kemampuan dalam pribadi Allah untuk merefleksikan diriNya agar dimengerti, diketahui oleh ciptaan-Nya. Kristus adalah hikmat Allah, karena Dia memiliki pengetahuan yang sebenarnya tentang Allah dan rencangan-Nya kepada semua ciptaan, khususnya manusia. MelaluiNya manusia memperoleh pengetahuan untuk mengetahui Allah dan rencana kekal-Nya bagi manusia. Pemahaman Logos dan Hikmat Allah bagi insan teologi adalah dengan memiliki Yesus sang Logos dan Firman Allah berarti merefleksikan Allah dan rancangan kekal-Nya bagi keselamatan manusia. Maka pemberitaan tentang Injil, pengajaran Kristen merupakan pengungkapan diri Allah bagi semua orang. Tanpa Kristus tidak ada seorangpun dapat mengungkapkan Allah kepada dunia.

\section{REFERENSI}

Agung, Athanasius, Erga 1: Enanthropiseos: Penjelmaan, (Thesaloniki: Grigorios Palamas, 1973. Palamas, 1973.

Erga 2: Kata Arion: Menentang Arianisme, (Thessaliniki: Grigorios

Erga 3: Menentang Arianisme, (Thessalonika : Grigorios Palamas, 1973.

Alkitab Indonesia Perjanjian Baru Indonesia -Yunani, 2010

Collins Greek-English Dictionary, Great Britian: HarperCollins Publisher, 2003

Pollard, T.E, Johannine Christology and the Early Church, (Cambridge: University Press: 1970.

Stephanidou, Sejarah Gereja: Pembentukkan Dogma Pengajaran Kristen, (Athena: Papadimitriou Publishing, 1998.

Samuel. V.C, The Council of Chalcedon Re-examined. A Historical and Theological Survey, (India, Madras" The Diocean Press, 1977.

The Orthodox Study Bible, New Testament and Psalm, (USA, Tennessee: Conciliar Press, 1977.

Zisis, Theodoros, $i$ Sotiria tou Anthropou kai tou Kosmou, Keselamatan Manusia dan Dunia, (Thessaloniki: Purnara, 1992. 